\title{
An Empirical Study of Chinese Inflation Time Lag
}

\author{
Huan Chen \\ School of International Business \\ Southwest University of Finance and Economics \\ Jinsha 2, Room 530, Southwest University of Finance and Economics \\ NO.55, Guanghuacun Street, Qingyang District \\ Chengdu 610074, China \\ E-mail: chenhuan_369@126.com
}

\begin{abstract}
Based on the current serious inflation problem at home and abroad, this thesis uses the data of broad money supply and monthly price during 1998 to 2008 and makes an empirical study on Chinese inflation time lag. Through the estimation of the Polynomial Distributed Lags Model, the author concludes that: money supply's change has significant time lag effect on price's change, and the lag time is about half a year; the effect is durative and the time is around 5 quarters; the impact of the time lag effect increases at first and then decreases, and its structure is $\Lambda$
\end{abstract}

Keywords: Currency Inflation, Time Lag Effect, Explanatory Variables, Explained Variables

\section{The Proposing of the Question}

In the first half of this year, Chinese domestic prices of goods rose continuously, and the problem of currency inflation has become very prominent in society. Therefore, the goal of preventing the economy from being overheating and the rising prices from developing to inflation has been put forward by government in March. Moreover, controlling the growth rate of inflation at around 4.8 percent has also been taken as the first task of the government. Here, we could know how serious the impact of inflation has been. At almost the same time, the phenomenon of inflation occurred in other countries were also serious which even brought riots. All of these show that the current inflation has become a common problem in the world.

There are kinds of reasons to breed inflation. On one hand, the expansion of social demand and the shrink of supply could raise the price level; on the other hand, the increase of money and government expenditure, as well as the move downwards of the demand's curve could also cause inflation. Nowadays, more economists believe that the growing supply of money is the main reason of inflation. However, the increasing in money supply will not cause price to rise immediately because of time lag aroused by velocity of money circulation and other factors. As a stock variable, the incessant accumulation of intensifies the risk of inflation. But how long it will be manifest in the form of inflation due to the time lag of money supply? That is the focus of research to this thesis.

\section{Literature Review}

According to Fisher's Formula, we how MV $=$ PQ. Here M represents that the average number of currency in circulation during a certain period; $V$ represents the velocity of money circulation; $P$ represents the price index of goods and services and $\mathrm{Q}$ represents transaction volume of goods and services. Fisher recognized that $\mathrm{V}$ and $\mathrm{Q}$ are invariable because $\mathrm{V}$ is decided by social system and custom and $\mathrm{Q}$ is stable under the condition of sufficient employment. Therefore, to some extent, the formula means the Quantity Theory of Money. In addition, the theory provides an interpretation that the change of price level only comes from money quantity. That is to say, $\mathrm{P}$ changes at the same ratio as M. But in reality, monetary policy has time lag effect which refers to the time between adjusting monetary policy and the occurring of its impact on economy when the economic situation changes. It is mainly composed of internal time lag and external time lag. The former refers to the interval from the need to take measures to correct economic changes to the central bank starts to take monetary policy tools, and the latter means the interval from the starting to the monetary policy tools impact on the object of it. In this thesis, it focuses on the external time lag.

Western scholars studied the time lag of monetary policy long time ago. After studying the relationship between money supply and price, Hume concluded that the quantity of money, whether it goes up or down, could not lead to the 
changes of price immediately. There was always an intermission before the old situation adjusting to a new one. Keynes studied the factors restricting the role of monetary policy in the process of time lag effect, and focused his research on the transmission mechanism of money. In he view, the transmission process of monetary policy was indirect and fiscal policy was direct. Therefore, the effectiveness of monetary policy was slow and it needed at least one year to demonstrate its role. Because of the "stagflation" problem occurred in the early 1970s, some western scholars paid attention to the interval of money supply's change started to affect economy. Here Friedman was the most successful. After a large number of empirical studies, he found that it needed approximately $6-9$ months from the changes of monetary supply to the changes of nominal national income and output, and it also needed approximately $6-9$ months from the changes of nominal national income and output to the changes of price. So the time lag is about one or one and a half years from the changes of monetary supply to the changes of price.

In recent years, the time lag effect of Chinese monetary policy has been causing concern of economists and they have achieved gratifying results. Chaoyu Zheng (1994) recognized that the external time lag was surely more than a quarter. DaShu Wang (1995) viewed that the external effect of monetary policy would show out until a few months or even ten months after it was implemented. XianBing Zheng (1995) showed his studies that Chinese economic output time lag was about 5 quarters, and the price's was about $4-5$ months. Whether monetary policy was tightening or expansion, the price time lag was shorter than the output's. YuanXun Mai, YeTian (2004) made use of VAR model and Variance Decomposition to study the time lag of Chinese monetary policy, and concluded that the time lag is 6 months, whether it was output or price's. He also concluded that the time lag was longer than the output's and that different money supply lead to different time lag. Gang Dong (2008) used VAR models and Impulse Response Function and quarterly data from 1996 to 2006, and concluded that the time lag caused by rate was 3 quarters and money supply was 2 quarters. He also got the result that the monetary policy time lag existed in both national output and price level. Combined with these previous researches, this thesis will explore this question by mainly using Polynomial Distributed Lags Model.

\section{Model Specifications}

This thesis is a study on the time lag of inflation, so the Polynomial Distributed Lags Model is a better choice. This model describe how the past lag variables impact on the current variables, and it can contact the different stages of economic phenomenon to each other and turn the static analysis of the economic activity into dynamic analysis which can explain the real economy better. The general form of the model is as following:

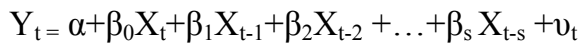

Here, $s$ stands for the length of the time lag, $\beta_{0}$ stands for the spot multiplier which means that the impact of a unit change of current $\mathrm{X}$ on $\mathrm{Y} ; \beta_{\mathrm{i}}(\mathrm{i}=1,2, \ldots, \mathrm{s})$ stands for the delay multiplier, which means that the impact of a unit change of past X on $\mathrm{Y}$. To the selection of variable, the author collects the data of national broad money supply $\left(\mathrm{M}_{2}\right)$ and

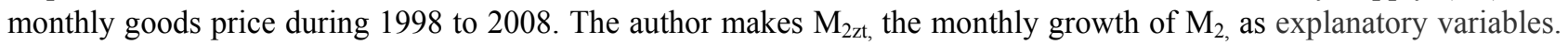
And the author makes the consumer price index $\mathrm{CPI}_{t}$ as explained variable. Put the two variables into the general model, we can get this:

$\mathrm{CPI}_{\mathrm{t}=\alpha} \alpha+\beta_{0} \mathrm{M}_{2 \mathrm{zt}}+\beta_{1} \mathrm{M}_{2 \mathrm{zt}-1}+\beta_{2} \mathrm{M}_{2 \mathrm{zt}-2}+\ldots+\beta_{\mathrm{s}} \mathrm{M}_{2 \mathrm{zt}-\mathrm{s}}+\mathrm{v}_{\mathrm{t}}$

\section{Model Estimation}

Before estimate the above-mentioned model, we should estimate this model:

$\mathrm{CPI}_{\mathrm{t}=} \alpha+\beta_{0} \mathrm{M}_{2 \mathrm{zt}}+\mathrm{v}_{\mathrm{t}}$,

The result is as following:

Insert Table1, Table2, Table3, Table4

Of course, from the above result, we can see that the $\mathrm{R}^{2}$ of regression equation is not large and DW value is low. That means there are other factors that affect price changes except for money supply; at the same time, too many lag variables may cause Multi - Linear problem. But if we only focus on the analysis of the time lag of money supply' change to price's, the above result is enough. We can change the model if we want to improve the forecast accuracy of it.

\section{Conclusion}

Through all these analysis, we can make such a conclusion: money supply's change has significant time lag effect on price's change, and the lag time is about half a year; the effect is durative and the time is around 5 quarters; the impact of the time lag effect increases at first and then decreases, and its structure is $\Lambda$.

\section{References}

Cong Wang, J. (2001). The Analysis and Countermeasures of Chinese Time lag effect of monetary policy, Chinese Economic Problem. 
DaShu Wang, J. (1995). The Measurement and Analysis of Currency Time Lag, Economic Research.

MaiYuan Xun \& YeTian J. (2004). An Empirical Study on Time Lag of Chinese Money Policy, Commercial Research.

Hao Pang, M. (2007). Econometrics. Science Press.

Table 1.

Dependent Variable: CPIT

Method: Least Squares

Date: $12 / 11 / 08 \quad$ Time: $11: 16$

Sample (adjusted): 1998M01 2008M10

Included observations: 130 after adjustments

\begin{tabular}{lllll}
\hline \hline Variable & Coefficient & Std. Error & t-Statistic & Prob. \\
\hline \hline C & 101.6791 & 0.308083 & 330.0385 & 0.0000 \\
M2ZT & -0.066876 & 0.092728 & -0.721208 & 0.4721 \\
\hline \hline R-squared & 0.004047 & Mean dependent var & 101.5231 \\
Adjusted R-squared & -0.003734 & S.D. dependent var & 2.496246 \\
S.E. of regression & 2.500902 & Akaike info criterion & 4.686445 \\
Sum squared resid & 800.5775 & Schwarz criterion & 4.730561 \\
Log likelihood & -302.6189 & F-statistic & 0.520141 \\
Durbin-Watson stat & 0.054758 & Prob(F-statistic) & 0.472097
\end{tabular}

From the regression result, the $\mathrm{t}$ statistic of $\mathrm{M}_{2 \mathrm{t}}$ is not significant, which indicates the current money supply's change has not obvious impact on current level of price. In order to analyze the time lag of money supply's change to goods price, we estimate 3 months-lag of the model, the result is as following: 
Table 2.

Dependent Variable: CPIT

Method: Least Squares

Date: 12/11/08 Time: 11:21

Sample (adjusted): 1998M04 2008M10

Included observations: 127 after adjustments

\begin{tabular}{lclll}
\hline \hline Variable & Coefficient & Std. Error & t-Statistic & Prob. \\
\hline \hline C & 101.6694 & 0.409418 & 248.3265 & 0.0000 \\
M2ZT & -0.116550 & 0.109715 & -1.062295 & 0.2902 \\
M2ZT(-1) & -0.035532 & 0.100117 & -0.354903 & 0.7233 \\
M2ZT(-2) & 0.009164 & 0.099894 & 0.091735 & 0.9271 \\
M2ZT(-3) & 0.093499 & 0.109816 & 0.851420 & 0.3962 \\
\hline \hline R-squared & 0.012328 & Mean dependent var & 101.5520 \\
Adjusted R-squared & -0.020054 & S.D. dependent var & 2.518057 \\
S.E. of regression & 2.543181 & Akaike info criterion & 4.743282 \\
Sum squared resid & 789.0678 & Schwarz criterion & 4.855258 \\
Log likelihood & -296.1984 & F-statistic & 0.380705 \\
Durbin-Watson stat & 0.064998 & Prob(F-statistic) & 0.822073 \\
\hline \hline
\end{tabular}

From the regression result, the lag factor of $\mathrm{M}_{2 \mathrm{zt}}$ increases gradually, which shows that the impact of current money supply's change on price level will emerge gradually after a period of time. However, the $t$ statistics of the lag factors is not significant, so we can not judge how long the time lag is. Therefore, we have to estimate 6 months-lag of the model, the result is as following: 
Table 3 .

Dependent Variable: CPIT

Method: Least Squares

Date: 12/11/08 Time: 11:22

Sample (adjusted): 1998M07 2008M10

Included observations: 124 after adjustments

\begin{tabular}{lcccc}
\hline \hline Variable & Coefficient & Std. Error & t-Statistic & Prob. \\
\hline \hline C & 101.3524 & 0.442888 & 228.8444 & 0.0000 \\
M2ZT & -0.167980 & 0.108947 & -1.541860 & 0.1258 \\
M2ZT(-1) & -0.112311 & 0.109713 & -1.023681 & 0.3081 \\
M2ZT(-2) & -0.069705 & 0.108944 & -0.639826 & 0.5235 \\
M2ZT(-3) & -0.038630 & 0.116076 & -0.332794 & 0.7399 \\
M2ZT(-4) & 0.087041 & 0.108945 & 0.798943 & 0.4260 \\
M2ZT(-5) & 0.146090 & 0.109630 & 1.332578 & 0.1853 \\
M2ZT(-6) & 0.259466 & 0.109391 & 2.371912 & 0.0193 \\
\hline \hline R-squared & 0.090659 & Mean dependent var & 101.6105 \\
Adjusted R-squared & 0.035785 & S.D. dependent var & 2.518898 \\
S.E. of regression & 2.473418 & Akaike info criterion & 4.711420 \\
Sum squared resid & 709.6646 & Schwarz criterion & 4.893374 \\
Log likelihood & -284.1081 & F-statistic & 1.652130 \\
Durbin-Watson stat & 0.117385 & Prob(F-statistic) & 0.127743 \\
\hline
\end{tabular}

Table 3 shows that the $\mathrm{t}$ statistics from $\mathrm{M}_{2 \mathrm{zt}}$ to $\mathrm{M}_{2 \mathrm{zt}-5}$ are not significant but $\mathrm{M}_{2 \mathrm{zt}-6}$ is significant under the $5 \%$ significance level. That is to say, the impact of current money supply's change on price level will emerge in the sixth month clearly. In order to study how long the time lag will be, we estimate 6 months-lag of the model, 9 months-lag, 12 months-lag, 15 months-lag, 18 months-lag, 21 months-lag and 24 months-lag step by step, and finally we find that the $t$ statistics of lag factors from $22_{\text {st }}$ month start to become insignificant. To the regression coefficient, the change of money supply begins to impact goods price obviously from sixth month and it comes to a head until the $21_{\text {st }}$ month, then it declines gradually. The result is showed in Table 4. 
Table 4.

Dependent Variable: CPIT

Method: Least Squares

Date: 12/11/08 Time: 11:41

Sample (adjusted): 2000M01 2008M10

Included observations: 106 after adjustments

\begin{tabular}{|c|c|c|c|c|}
\hline Variable & Coefficient & Std. Error & t-Statistic & Prob. \\
\hline $\mathrm{C}$ & 98.81613 & 0.354303 & 278.9028 & 0.0000 \\
\hline M2ZT & -0.183914 & 0.072251 & -2.545485 & 0.0128 \\
\hline M2ZT(-1) & -0.158488 & 0.075283 & -2.105210 & 0.0384 \\
\hline M2ZT(-2) & -0.124133 & 0.074974 & -1.655691 & 0.1017 \\
\hline M2ZT(-3) & -0.112983 & 0.075057 & -1.505302 & 0.1362 \\
\hline M2ZT(-4) & -0.053793 & 0.075185 & -0.715473 & 0.4764 \\
\hline M2ZT(-5) & -0.017812 & 0.077873 & -0.228726 & 0.8197 \\
\hline M2ZT(-6) & 0.059975 & 0.076119 & 0.787907 & 0.4331 \\
\hline M2ZT(-7) & 0.050479 & 0.076752 & 0.657691 & 0.5126 \\
\hline M2ZT(-8) & 0.068308 & 0.077353 & 0.883069 & 0.3798 \\
\hline M2ZT(-9) & 0.012064 & 0.081737 & 0.147594 & 0.8830 \\
\hline M2ZT(-10) & 0.039505 & 0.085335 & 0.462939 & 0.6447 \\
\hline M2ZT(-11) & 0.038666 & 0.086098 & 0.449089 & 0.6546 \\
\hline M2ZT(-12) & 0.131446 & 0.085698 & 1.533823 & 0.1290 \\
\hline M2ZT(-13) & 0.127115 & 0.081982 & 1.550526 & 0.1250 \\
\hline M2ZT(-14) & 0.107226 & 0.084880 & 1.263270 & 0.2102 \\
\hline M2ZT(-15) & 0.091463 & 0.086023 & 1.063230 & 0.2909 \\
\hline M2ZT(-16) & 0.084634 & 0.085505 & 0.989820 & 0.3252 \\
\hline M2ZT(-17) & 0.096857 & 0.088445 & 1.095111 & 0.2768 \\
\hline M2ZT(-18) & 0.126879 & 0.087556 & 1.449106 & 0.1512 \\
\hline M2ZT(-19) & 0.164404 & 0.089828 & 1.830221 & 0.0709 \\
\hline M2ZT(-20) & 0.174413 & 0.089303 & 1.953051 & 0.0543 \\
\hline M2ZT(-21) & 0.194708 & 0.091654 & 2.124386 & 0.0367 \\
\hline M2ZT(-22) & 0.173142 & 0.092817 & 1.865416 & 0.0658 \\
\hline M2ZT(-23) & 0.103975 & 0.097326 & 1.068318 & 0.2886 \\
\hline M2ZT(-24) & 0.106052 & 0.098557 & 1.076049 & 0.2851 \\
\hline R-squared & 0.792364 & \multicolumn{2}{|c|}{ Mean dependent var } & 102.1142 \\
\hline Adjusted R-squared & 0.727478 & \multicolumn{2}{|c|}{ S.D. dependent var } & 2.373482 \\
\hline S.E. of regression & 1.239045 & \multicolumn{2}{|c|}{ Akaike info criterion } & 3.475712 \\
\hline Sum squared resid & 122.8186 & \multicolumn{2}{|c|}{ Schwarz criterion } & 4.129009 \\
\hline Log likelihood & -158.2127 & \multicolumn{2}{|c|}{ F-statistic } & 12.21158 \\
\hline Durbin-Watson stat & 0.342002 & \multicolumn{2}{|c|}{ Prob(F-statistic) } & 0.000000 \\
\hline
\end{tabular}

